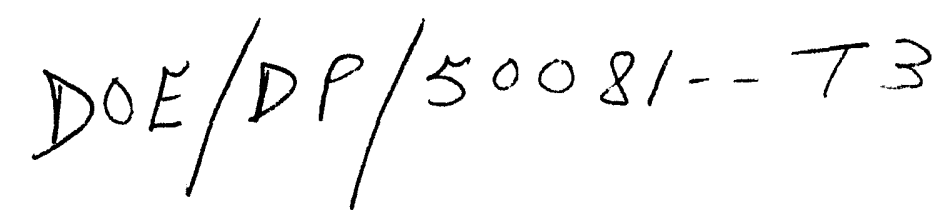

\title{
A Chronology of \\ Comprehensive Test Ban \\ Proposals, Negotiations, and \\ Debates: 1945-1993
}
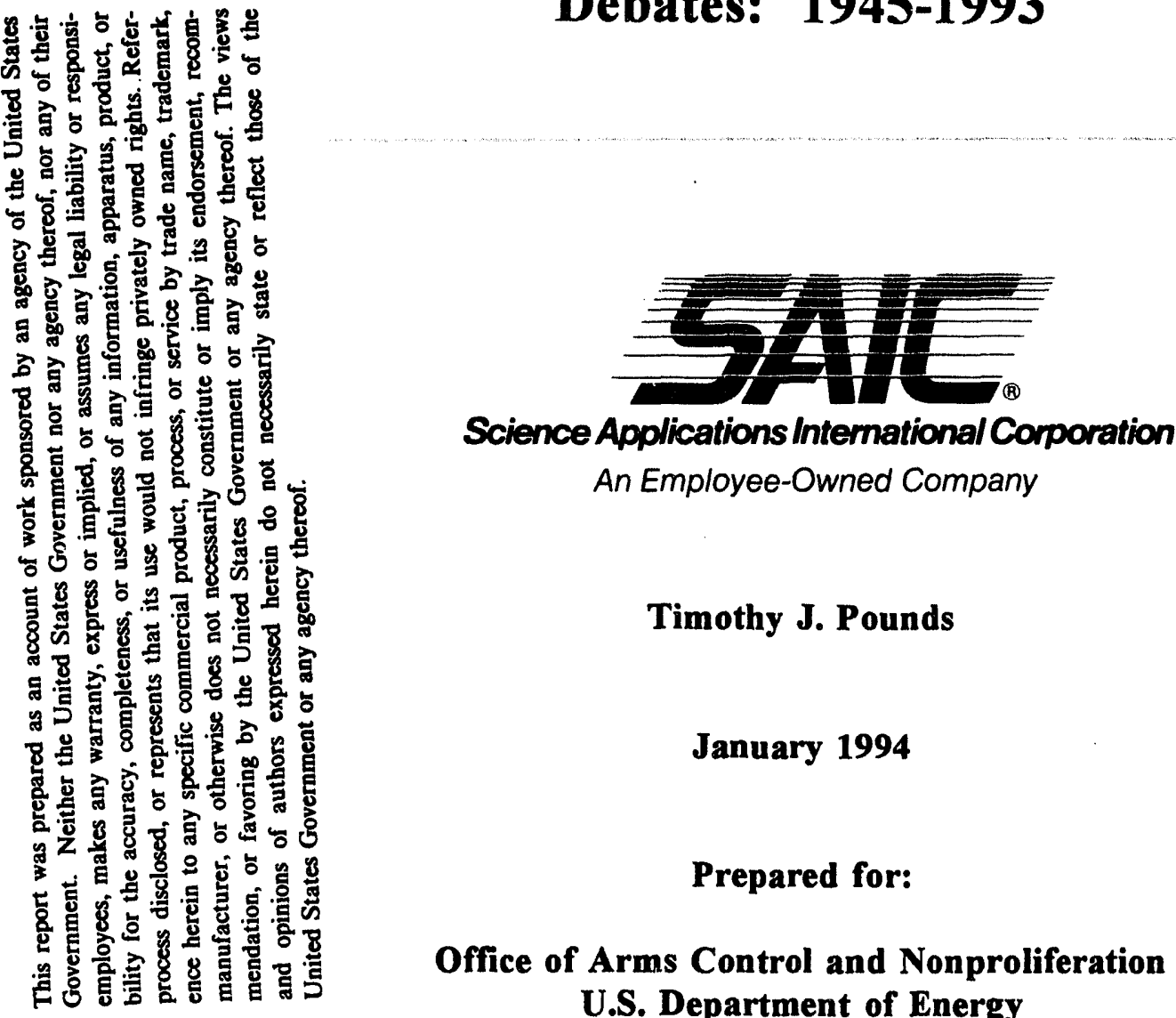

An Employee-Owned Company

Timothy J. Pounds

January 1994

Prepared for:

Office of Arms Control and Nonproliferation

U.S. Department of Energy

Contract No. DE-AC01-92DP50081

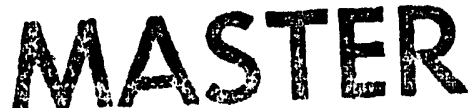

This paper represents the views of its author, not necessarily those of its sponsor or any other U.S. Government agency. 


\section{CTB CHRONOLOGY, 1945-1993}

1945

July: U.S. conducts first nuclear test ("TRINITY" explosion) at Alamagordo Air Base, New Mexico -- 19 KT (kilotons).

Aug: U.S. drops atomic bomb on Hiroshima -- $15 \mathrm{KT}$-- resulting in approximately 140,000 deaths.

U.S. drops atomic bomb on Nagasaki -- $21 \mathrm{KT}$-- causing approximately 70,000 deaths.

1946

Mar: Acheson-Lilienthal Report released, supporting the creation of an international authority to control nuclear weapons and materials.

-- This scheme reflects emphasis of early postwar arms control on general and complete disarmament, with an insistence on extensive and intrusive on-site inspection to establish "control" regime.

June: Based largely on Acheson-Lilienthal Report, U.S. proposes Baruch Plan to establish nuclear disarmament and international control over all nuclear activities.

-- Plan would have obligated countries to turn over all nuclear activities to an international agency and to accept unlimited inspections. The international agency would have reported violations to the U.N. Security Council for further prescribed responses. Soviets reject.

1949

Aug: U.S.S.R. explodes first atomic bomb, "Joe 1" - 10-20 KT.

Oct: Atomic Energy Commission (AEC) General Advisory Committee recommends against development of thermonuclear weapons. Robert Oppenheimer, David Lilienthal, and majority of scientists advising AEC oppose effort on technical and/or moral grounds.

Jan: With support from the Congressional Joint Committee on Atomic Energy, President Truman announces decision to go ahead with H-bomb project. Six months later, the White House orders a crash program to produce tritium for the project. 
$\underline{1951}$

April-

May: Operation "Greenhouse" test confirms principle of thermonuclear burning.

June: Teller presents breakthrough on H-bomb to panel of scientists at Princeton's Institute for Advanced Study. Further work on H-bomb continues.

Truman appoints a five-member committee to advise him on disarmament policy. Members include Robert Oppenheimer, Vannevar Bush, and Allen Dulles.

$\underline{1952}$

Oct: Britain explodes first atomic bomb at Monte Bello Islands (near Australia).

Presidential advisor Vannevar Bush suggests the cancellation of upcoming thermonuclear test and urges proposal to ban all hydrogen detonations, claiming that this would be the last chance to avoid a thermonuclear weapon arms race. Truman orders test to proceed when he learns that weather conditions would force a six-month delay if test is postponed.

Nov: U.S. explodes its first full-scale, 62-ton thermonuclear device "Mike" (using liquid tritium and deuterium) at Enewetak Atoll -- $10 \mathrm{MT}$ (megaton).

Aug: U.S.S.R. explodes one-stage fission/fusion bomb "Joe 4" using dry hydrogen isotopes -- 200 $300 \mathrm{KT}$.

Mar-

Dec: U.S. explodes first full-scale thermonuclear bomb "BRAVO" at Bikini Atoll -- $15 \mathrm{MT}$. Bomb uses lithium- 6 deuteride.

-- Yield is significantly higher than expected. Explosion contaminates wide areas in Pacific and exposes 236 residents of the Marshall Islands and 28 Americans to radiation. Crew of Japanese fishing boat "Lucky Dragon" 100 miles from explosion also exposed and one crew nember dies in September.

U.N. establishes Five-Nation Disarmament Subcommittee (April 19).

Press coverage of BRAVO triggers national and international scrutiny of dangers of fallout and arms race. 
-- Congress announces that it will conduct investigation of BRAVO and failure of the AEC to take proper precautions against radioactive fallout. Experts begin open debate on whether to stop testing altogether. Advocates of a test ban point to healih and security risks of continued testing. U.S. government and testing supporters maintain that it is infeasible to ban tests without proper verification and that testing is necessary to deter Soviet aggression. Government sprikesmen also attempt to allay public fears about the effects of fallout from nuclear weapons tests.

-- In press conference (7 April), Eisenhower states that "We know of no military requirements that could lead us to the production of a bigger bomb than has already been produced." Meanwhile, Secretary of State John Foster Dulles holds a secret ministerial with NATO allies (23 April) to reinforce fact that nuclear weapons are only way U.S. can protect Europeans against superior Soviet conventional forces and to warn against any form of self-imposed unilateral disarmament.

-- International concerns emerge about the effects of testing and first calls for test ban. Japanese government demands that U.S. government conduct formal inquiry while left-wing Japanese students demonstrate against testing. In April 2 speech to Indian Parliament, Prime Minister Nehru proposes a "standstill agreement" on nuclear testing while United Nations works out a comprehensive disarmament agreement. He closes speech by noting that "It is of great concern to us that Asia and her peoples appear to be always nearer to these occurrences and experiments and their fearsome consequences, actual or potential." In the U.K., the Labor Party introduces a resolution in late March asking the government to seek a summit meeting with the Soviet Union to arrange for the suspension of all testing; endorsed by London Times. Prime Minister Churchill argues for $\mathrm{H}$-bomb as best deterrent, but eventually promises to seek a summit on nuclear weapons with the U.S. and U.S.S.R. Pope Pius XII, stopping short of advocating a test ban, notes dangers of nuclear arms race and wisdom of comprehensive disarmament.

Feb: AEC report on BRAVO shot released. Contends health risks of testing are minute compared to the advantages gained for "the security of the nations of the free world." National press continues coverage of dangers of radiation fallout, effects of nuclear war, and need for civil defense.

Operation "TEACUP" atomic tests held in Nevada (February 18-May 15).

In press conference (23 February), Eisenhower states that test ban has been studied and rejected, and that administration will pursue comprehensive disarmament.

Prime Minister Churchill announces that Britain has discovered the secret of the H-bomb and will proceed to build its own thermonuclear weapons. Defends notion of defense through deterrence.

Mar: Eisenhower appoints Harold Stassen as advisor and interagency coordinator for disarmament policy. 
-- After full interagency study, Stassen advises Eisenhower that a moratorium on H-bomb testing would not be in the interest of the U.S. and should not be pursued except as a part of a comprehensive disarmament plan.

Apr: Leaders of Asian and African nations meet at Bandung in Indonesia. Conference resolution calls for prohibition of production, experimentation, and use of nuclear weapons, and a suspension on testing pending negotiation of such a ban.

May: U.K. Conservative Party's Anthony Eden wins election to succeed Churchill; supports deterrence strategy but commits his government to goal of seeking new international efforts at disarmament.

During Five-Nation U.N. Disarmament Subcommittee talks in London, Soviets propose on May 10 the discontinuation of nuclear testing under supervision of an international commission, as part of a two-stage comprehensive disarmament plan.

-- Departing from earlier proposals, the Soviets suggest the creation of control organ, which "shall establish on the territory of all the States concerned on a basis of reciprocity, control at large ports, at railway junctions, on main motor highways and in aerodromes." Initially, the U.S. gives neutral response to test ban idea, but Western governments react positively to the idea of establishing a control mechanism. The proposal stimulates a reappraisal by the U.S. Government of Soviet iricentions and U.S. disarmament goals.

Aug: U.S.-U.S.S.R. Geneva Summit: U.S. proposes Open Skies as a means of preventing surprise nuclear and conventional attacks and as a catalyst for comprehensive arms control agreement. Soviets reject, but agree to further study of idea.

Nov: In second test of series, U.S.S.R. detonates thermonuclear device at Semipalatinsk -- 1.6 MT. Japan reports radioactive rain and Europe experiences sharp increase in atmospheric radiation.

In reply to Soviet's May test ban proposal, Secretary of State Dulles states (on 11 November) that any such proposal would have to include proper safeguards, including inspection by an international agency, before it could be considered.

-- Soviets offer a reciprocal suspension of nuclear tests (November 28).

-- On November 29, Dulles states that, after several months of study, U.S. has been unable to find a formula which would be "both dependable and in the interests of the United States." He promises further study and consideration of the issue.

Dec: At the of a State visit to India, Secretary General Khrushchev issues a joint communique with Prime Minister Nehru (December 13) calling for an "unconditional prohibition of the production, use and experimentation of nuclear and thermonuclear weapons."

U.N. General Assembly creates scientific committee to study radiation hazards.

In Christmas eve address, Pope Pius recalls his concern over radiation hazards and proposes a three-part disarmament plan linking a test ban to the elimination of nuclear weapons and establishment of effective international supervision. 
Jan: Secretary of State Dulles states that the U.S. has not discovered any rationale for suspending nuclear testing. He notes that Stassen is working on a general disarmament proposal and that a test ban will have to wait until a comprehensive plan with proper inspection safeguards could be formulated.

Senate Foreign Relations Committee creates disarmament subcommittee, establishing new forum for discussion on testing. Chaired by Hubert Humphrey, this subcommittee holds series of twelve hearings over the next year.

-- Administration officials continue to argue that without reliable system of detection, test ban remains undesirable.

Mar: At the Spring session of the U.N. Disarmament Subcommittee, Soviets present plan for gradual reduction of conventional forces linked to a ban on all nuclear tests.

-- U.S. rejects plan on grounds that it lacks verification provisions. England, France, and Canada promote compromise plan including reduction of nuclear and conventional forces, nuclear testing limits, and provisions for international supervision. Session ends in deadlock.

Soviets begin unannounced test series. U.S. Government makes routine announcement of its occurrence, but minimizes publicity.

Apr: AEC Commissioner Thomas Murray suggests to Humphrey subcommittee that the U.S. unilaterally forego any further tests of $\mathrm{H}$-bombs, seek an international moratorium on $\mathrm{H}$-bomb tests, and pursue a sharp increase in testing and production of tactical nuclear weapons. Murray explains that his goal is to develop balanced nuclear arsenal as deterrent to war and to concentrate on building weapons that are useful for war fighting.

Adlai Stevenson, Democratic Presidential candidate, proposes ban on H-bomb tests in speech to American Society of Newspapers (April 21).

-- Eisenhower replies (April 25) that H-bombs are necessary element of missile-based nuclear deterrent. He says U.S. will continue to test, not to develop a more destructive bomb, but to perfect it for a variety of military uses.

May: U.S. begins to conduct series "REDWING," (May 21-July 21) that includes 10-MT high-altitude blast over Namu Island in Bikini Atoll. Spread of fallout is minimal.

June: National Academy of Sciences releases report on radiation hazards of testing. Scientists conclude that nuclear weapons tests had not raised worldwide radiation to dangerous levels, and that X-rays posed a greater danger. However, report does mention potential long-term problems on genetic effects of increased exposure to radiation and the potential hazards associated with the uptake of strontium-90.

Aug-

Sept: Soviets conduct nuclear tests in Siberia. 
-- Instead of playing down Russian nuclear explosions as it had done in the past, Eisenhower administration launches publicity campaign to discredit Russian testing.

-- Soviets respond with renewed call for international test ban agreement. Soviet Premier Marshall Bulganin sends formal proposal to President Eisenhower (September 11) calling for a halt to atomic and H-bomb tests, while dismissing the need for international supervision.

-- Eisenhower authorizes the National Security Council (NSC) to restudy test ban issue.

Sept-

Nov: Test ban issue becomes heated during Presidential campaign.

-- Adlai Stevenson proposes to halt further testing of "large nuclear devices, conditional upon adherence by the other atomic powers." In later speech, Stevenson denies Republican charges that he favors unilateral disarmament, arguing that he wants U.S. to take the lead in curtailing all nations of H-bomb tests. In a speech in Minneapolis (September 29), he states that if U.S. stopped testing and Soviets did not, "at least the world will know we tried." Stevenson also argues the U.S. should stop testing to minimize the dangers of poisoning the atmosphere.

-- October 6 White House press release details four main objections to a unilateral test ban: (1) nuclear weapons are needed to offset superior Communist conventional forces, (2) continued testing is needed to reduce fallout from H-bombs, (3) testing is necessary to preserve present U.S. lead in nuclear weapons, and (4) it would be wise to avoid partisan distortion of this complex issue.

-- In nationally televised speech (October 15), Stevenson states that both U.K. and U.S.S.R. have expressed willingness to stop testing, and the U.S. should too. He argues that the U.S. should pursue a test ban because: (1) the U.S. possesses bombs large enough to destroy entire cities and does not need weapons that are more powerful; (2) a test ban would not require inspection, since any violation could be detected; (3) a test ban would halt the spread of nuclear weapons to other countries; and (4) it would spare the world from the hazards of fallout.

-- State Department releases on October 19 a letter from Soviet Premier Bulganin to Eisenhower, in which Bulganin repeats his offer to ban nuclear testing, notes that "certain prominent public figures in the U.S." support this idea, and points out that it would be impossible to detonate a nuclear explosion secretly. U.S. press reacts negatively to Soviet interference in U.S. election. Stevenson continues to focus on testing, but by late October, a Gallup poll reveals that 56 per cent of respondents oppose calling off H-bomb tests.

Suez Crisis (October 29) and Soviet invasion of Hungary (November 4). On November 6, Eisenhower wins 58 per cent of the popular vote. 
Jan: U.S. Ambassador Henry Cabot Lodge presents five-point disarmament proposal to United Nations.

-- It calls for an end to production of nuclear weapons, subject to strict international supervision. Once this goal is achieved, U.S. willing to negotiate a treaty to eliminate all nuclear test explosions. Proposal includes reductions in conventional forces, notification of intercontinental ballistic missile (ICBM) tests, and variation of Open Skies. U.S. also offers to negotiate an interim agreement requiring all nuclear tests to be announced in advance and permit limited international observation. Russians reject.

Soviets conduct nuclear tests in Siberia (January 19-April 26).

Mar: Eisenhower and U.K. Prime Minister Harold Macmillan meet in Bermuda and devote considerable time to discussing test ban issues.

-- Final communique states their agreement that continued testing is required, "certainly for the present." They renew U.S. offer to register all tests in advance and permit limited observation if Soviets do likewise.

May: Britain conducts first thermonuclear test at Christmas Islands.

Eisenhower approves NSC concept for a temporary test ban proposal (May 25).

June: U.S.S.R. proposes cessation of testing for 2-3 years with monitoring conducted by an international commission (as part of its comprehensive arms control proposal known as "Ground Control Posts," the first version of which was presented on May 10, 1955).

AEC begins Project "PLOWSHARE" to investigate nonmilitary uses of nuclear programs. Between 1957 and 1973, the project involves a total of 48 peaceful nuclear explosions (PNEs) to explore projects including isotope generation, earth moving, and oil and gas stimulation. (Project is officially terminated in 1977.)

Aug: President Eisenhower proposes suspension of nuclear testing for up to two years, linked to a fissionable materials production cutoff (August 29). Soviets reject this linkage.

Soviets begin series of $6 \mathrm{H}$-bomb tests in Pacific.

Sept: U.S. conducts first contained underground test "RAINIER" at Nevada test site $-1.7 \mathrm{KT}$.

Oct: Soviets launch Sputnik.

Nov: Eisenhower appoints James Killian to new post of adviser for science and technology. 
Feb-

Mar: Soviets conduct series of nine H-bomb tests in Siberia (February 22-March 27).

Mar: On March 31, U.S.S.R. announces unilateral moratorium on all nuclear tests if Western nations also stop; it does not enter into effect until several months later.

Apr: Killian presents Scientific Advisory Committee recommendation for a CTB to Eisenhower (April 17). Committee concludes that, based on data from the "RAINIER" underground explosion, a test ban can be monitored with confidence. Committee also holds view that pursuit of a CTB would be in the interest of the United States given the advanced status of its nuclear weapons program.

Eisenhower proposes a Conference of Experts to examine how compliance with a test ban could be verified (April 28). Proposal separates testing from other disarmament issues. Although Soviets maintain that yerification poses no problems, Khrushchev agrees to Soviet participation in the conference.

U.S. begins HARDTACK I H-bomb tests in Pacific (April 28-August 12).

July: Conference of Experts (to Study the Possibility of Detecting Violations of a Possible Agreement on Suspension of Nuclear Tests) convenes in Geneva. Representatives from U.S., Britain, U.S.S.R., France, Canada, Czechoslovakia, Romania, and Poland gather and begin to discuss testing verification issues.

Aug: Experts' report released August 21 concludes that a control system composed of 160-170 incountry monitoring stations could detect and identify atmospheric explosions above $1 \mathrm{KT}$ threshold and underground explosions greater than $5 \mathrm{KT}$.

-- Report also recommends on-site inspections of unidentified or ambiguous events that could be suspected of being nuclear explosions.

In consultations with NATO allies, the U.S. announces its intention to pursue a ban on nuclear testing and undertake a moratorium.

-- France declares that it will continue with its nuclear weapons development program and is opposed to any limitation on testing. Britain protests that it has a test series planned for early fall and that any suspension should be delayed until its completion. Ultimately, however, Macmillan defers to U.S. position.

On basis of Experts' report, Eisenhower proposes on August 22 to begin tripartite U.S.-U.K.U.S.S.R. negotiations on October 31 with the aim of ending nuclear tests.

-- He also announces a test moratorium for the first year of talks, if the Soviets follow suit. Eisenhower states that the U.S. would be willing to extend the moratorium on a year-to-year basis, if a control system is installed and progress is made in other arms control areas. 
-- Soviets accept Eisenhower's proposal to begin negotiations, but do not commit themselves to the moratorium. They reject the linkage of a test ban to the establishment of a control mechanism or to progress in other arms control areas.

Sept: HARDTACK II atomic tests begin in Nevada (September 12-October 30).

U.K. conducts test series on Christmas Island (first shot was on August 22).

Soviets break their self-imposed moratorium and begin on September 30 a month-long series of 14 nuclear tests, many in the megaton yield range.

Oct: U.S., U.S.S.R., and Britain begin CTB talks in Geneva on October 31 in the Conference on the Discontinuance of Nuclear Weapons Tests.

Nov: Final Soviet nuclear test in fall series (November 3).

Senator Albert Gore Jr., proposes ban on atmospheric testing, arguing that the U.S. should only ban tests that can be verified with high confidence.

Jan: U.S. announces data from "HARDTACK II" underground tests in Geneva. New information directly disputes conclusions of Experts' report concerning requisite capabilities to detect and identify underground tests.

-- U.S. claims that several techniques might be used to evade detection, e.g., a 300-KT explosion in a large underground cavity could result in the same seismic signal as a 1-KT tamped explosion. The U.S. also expresses concern that explosions in space and at higher altitudes might go undetected.

-- The new data reopens debate on test ban within the Eisenhower administration. The Scientific Advisory Committee had recommended pursuit of a test ban on grounds that tests could be detected and identified. With this finding called into question, test ban opponents call for a reconsideration of U.S. position. AEC and Pentagon argue that since a ban on underground testing cannot be policed properly, the United States should restrict its negotiations to a limited ban on atmospheric testing. Eisenhower appoints a special panel of scientific experts under Lloyd Berkner to study the new evidence and report on its full implications and ways in which the detection system outlined in the experts' report could be strengthened.

-- In Geneva, Soviets reject HARDTACK II data and insist that negotiating parties are bound by the experts' report. In response to U.S. suggestion that a second technical experts meeting be convened, the Soviets accuse Eisenhower of trying to undermine the negotiations. In an effort to show good faith, Eisenhower drops earlier demand that progress on a test ban be linked to a cutoff of fissionable material production for weapons and progress on other arms control measures. Soviets continue to refuse attempts to include new test data in negotiations. 
Feb: U.K. Prime Minister Macmillan meets with Khrushchev and suggests that an annual quota for on-site inspections be set. Khrushchev shows interest in the compromise and Macmillan urges Eisenhower to propose it in Geneva.

-- Eisenhower agrees only to consider this compromise. He also gives increasing attention to suggestions of banning only those tests that can be verified with high confidence.

Mar: Berkner panel confirms earlier analysis of "HARDTACK II" evidence, claiming that there could be as many as 1500 suspicious events that would require on-site inspection below the 5-KT threshold.

-- Panel concludes that, if left unchanged, the Geneva system could not identify blasts with reasonable certainty below $20 \mathrm{KT}$. (Panel suggests that a 10-fold increase in seismographs at each post and the measurement of surface and underground shock waves would enable the system to identify underground tests down to $10 \mathrm{KT}$.) Panel estimates that an intensive program could restore initial 5-KT capability within 2-3 years.

Macmillan travels to Washington to discuss test ban impasse with Eisenhower (March 19-24). They agree to press for a more modest, enforceable agreement, with a 3-4 year ban on atmospheric tests.

Apr: Eisenhower writes to Khrushchev on April 13, proposing a ban on atmospheric tests under the altitude of $50 \mathrm{~km}$ as an interim measure, while negotiators continue to work out the details of a treaty banning underground and space tests.

-- U.S. representative in Geneva presents this proposal on the same day, explaining that such a ban could be enforced without on-site inspection and with as few as 8 control posts in Russia. U.S.S.R. responds with counter proposal for a CTB with a limited number of on-site inspections.

-- Eisenhower instructs U.S. delegation to explore idea of a predetermined number of inspections a year. In May press conference, Eisenhower notes that any annual quota will have to be based on scientific estimates of the likely number of suspicious events, not on political considerations.

June-

July: Technical Working Group I meets in Geneva to discuss problem of detecting high-altitude and space explosions (June 22-July 10).

Britain announces it will not resume testing as long as negotiations in Geneva continue.

Aug: U.S. announces on August 26 it will extend its moratorium until December 31.

U.S.S.R. announces it will not test until Western powers do.

Nov: Technical Working Group II meets in Geneva and fails to reach agreement on seismic detection issues. 
Dec: Eisenhower announces U.S. considers itself free to resume testing after moratorium expires, but that U.S. would announce resumption in advance.

Jan: $\quad$ Research and development of a world-wide seismic network (Project VELA) begins. (For FY 1960 and 1961, \$51.4 million appropriated; \$59 million for FY 1962).

-- Program has two main elements: (1) As part of the U.S. Coast and Geodetic Survey, U.S. offers to supply modern calibrated and standardized instrumentation to seismological stations all over the world, under the condition that copies of the records be made available to the Coast and Geodetic Survey. This program envisages providing instrumentation for 125 stations, most of them on foreign soil. U.S. officials state explicitly that purpose of stations is not to detect nuclear explosions in U.S.S.R., but rather to collect earthquake statistics. (2) Seismological stations in the U.S., which have the explicit purpose of detecting Soviet nuclear explosions.

Feb: On February 11, U.S. proposes ban on tests in the atmosphere, tests underwater, and tests underground greater than 4.75 on the Richter scale, with monitoring by on-site inspections. Signatories would also establish a joint seismic research program to discuss lowering of underground threshold.

On February 13, France detonates its first nuclear weapon in Sahara Desert.

Mar: Soviets offer counter proposal to add a ban on all tests in space and a 4-5 year unsupervised moratorium on tests below 4.75 on the Richter scale.

Eisenhower and Macmillan confer at Camp David and agree in principle to accept a moratorium of agreed duration on low-yield underground tests.

Apr: France conducts second test.

Joint Committee on Atomic Energy holds subcommittee hearings on technical challenges of detecting underground nuclear explosions.

-- Several experts give pessimistic appraisal of ability to monitor adherence with a test ban. Prominent members of Congress raise doubts whether Senate would support even a threshold test ban treaty and urge Eisenhower to seek concessions from Khrushchev on on-site inspections.

In late April, Senator Humphrey states that 20 inspections per year would be enough to secure Senate support, and Senator Gore reverses his position and announces support of a threshold test ban.

Test ban advocates are optimistic that outstanding issues can be resolved at upcoming Paris summit scheduled for May 16.

-- Major issues are: (1) number of on-site inspections per year; (2) length of moratorium on small underground tests; (3) composition of control system personnel; (4) the composition of the 
Control Commission; (5) the question of voting rights in the Commission; and (6) the degree of independence for the Control Commission administrator.

May: U.S. U-2 shot down over Sverdlosk (May 1).

-- After initial denials by the State Department that the plane was a U-2 or was spying, Eisenhower states on May 11 that he takes personal responsibility for U-2 mission, that U-2 missions have provided important intelligence since 1956, and that such flights would continue.

-- Arriving in Paris on May 14, Khrushchev makes it clear that he expects an apology from Eisenhover and an assurance that U-2 flights will cease over Soviet territory. On opening day of summit (May 16), Khrushchev denounces Eisenhower, withdraws invitation for Eisenhower to visit the Soviet Union, and suggests that the conference be rescheduled after the 1960 U.S. Presidential elections.

-- Eisenhower announces suspension of U-2 flights and pledges no more overflights in future. Khrushchev leaves conference, holds press conference denouncing the United States, and returns to Moscow. Negotiations in Geneva continue, but progress all but ceases.

Dec: France conducts third test.

$\underline{1961}$

Jan: President Kennedy orders a thorough review of U.S. position to determine what concessions could be offered to meet Soviet objections to the U.S. test ban position while not impairing U.S. security.

Mar-

Apr: Tripartite negotiations reconvene in Geneva.

- U.S. and U.K. present complete draft treaty for the first time that incorporates areas of agreement from the past conference, calling for ban on all tests except underground tests less than 4.75 on the Richter scale, a 3-year moratorium on such tests while verification research continues, and an annual quota of 20 inspections per year in the U.S.S.R. Western proposal also offers other concessions, e.g., Western draft would allow Soviets to inspect nuclear devices used in seismic research and the AEC's PLOWSHARE program.

- In a shift from their position, Soviets respond with proposal for creation of an Administrative Council, which could give member the right of veto on all decisions (as opposed to Western concept of a single administrator). Soviets also indicate informally that 3 inspections per year will be maximum acceptable.

France conducts fourth test (April 25).

May: Soviet Union states that if France continues testing, it will be compelled to resume testing.

June: Vienna Summit between Khrushchev and Kennedy. No breakthroughs on testing. 
Aug: On 30 August, U.S.S.R. announces its resumption of testing in light of French tests and Berlin crisis.

-- On 31 August, Khrushchev tells visiting delegation of British members of parliament that. he has decided to resume testing with a bomb of unprecedented proportions to shock the Western nations into negotiations on Germany and into accepting his demand that testing negotiations be merged with talks on complete disarmament.

-- Beginning on September 1, Soviet test series is largest ever conducted, with 30 atmospheric blasts in 60 days.

Sept: U.S. and Britain propose a ban on atmospheric tests with no inspections. Soviets reject.

Kennedy orders resumption of tests (September 5), confining authorization to laboratory and underground tests.

Oct: U.S.S.R. explodes nuclear device over Novaya Zemlya -- 58 MT.

Nov: Test ban negotiations resume in Geneva. Soviets table draft test ban, with verification details to be worked out after treaty. U.S. and Britain reject.

Kennedy announces preparation for atmospheric tests so that they could be undertaken if deemed necessary.

France conducts fifth test (November 7).

1962

Jan: Trilateral negotiations end in deadlock and adjourn indefinitely.

Mar: Kennedy announces decision to resume atmospheric testing, unless Soviets agree to Western test ban proposal by end of April.

\section{U.N. Eighteen Nation Committee on Disarmament (ENDC) convenes in Geneva.}

-- Soviets repeat proposal for test ban without agreed verification provisions. Soviets and U.S. present draft treaties for comprehensive disarmament. U.S. and U.K. suggest eliminating seismic threshold, 20 inspections per year, and establishment of a worldwide seismic network.

Apr: U.S. resumes atmospheric testing with operation "DOMINIC," a series of 40 atmospheric tests over 6 months. Includes "STARFISH" blast, a megaton yield test at 400 kilometers.

June: Secretary of Defense Robert McNamara announces elements of new strategic doctrine at commencement address at the University of Michigan.

-- He stresses the necessity of building up NATO's conventional forces to enable response other than nuclear strike in event of a limited attack. He also states that, "principal military 
objectives, in the event of a nuclear war stemming from a major attack on the alliance, should be the destruction of the enemy's military forces, not of his civilian population."

-- Implications are that U.S. rejects notion of counter-value deterrent and will require more nuclear weapons, but that the number required would be determined on a case-by-case basis. Shift in doctrine reflects administration's lessening interest in development of new, high-yield nuclear weapons. However, this shift also hints at need for more survivable, safe, reliable, and accurate nuclear weapons systems.

July: Arms Control and Disarmament Agency (ACDA) Director William Foster testifies to Senate Foreign Relations Committee that the evidence emerging from VELA program suggests that detecting underground explosions may not be as difficult as previously thought.

-- Most notably, U.S. has discovered that number of shallow earthquakes in U.S.S.R. are fewer than estimated -- 40 shallow earthquakes above seismic magnitude of 4.75 compared with estimate of 100 prior to VELA program. Foster also states that the sensitivity of seismographs could be increased by factor of 5-10 by placing them in deep holes rather than on the surface.

-- At the same time, Foster cautions that scientists have learned that the magnitude of the seismic signal depends greatly upon the surrounding medium of the test. Alluvium especially reduces the signal (by a factor of seven over tests conducted in tuff compared to those conducted in hard rock.) Still, he reports that scientists have discovered that tests in alluvium are likely to produce a surface cavity that could be seen from above.

Aug: After extensive review of alternatives, U.S. and Britain table two draft treaties in the ENDC: (1) a CTB with a seismic network and an inspection quota to be negotiated; or (2) a limited ban prohibiting all tests in the atmosphere and underwater, with no inspections. Soviets reject both, arguing that the first is unacceptable because it requires inspections, and the second undesirable because it allows testing to continue.

Soviets begin another test series, which includes a 30-MT explosion.

Sept: In hearings before the Preparedness Investigating Subcommittee, U.S. Department of Defense (DOD) Assistant Secretary for International Security Affairs Paul Nitze evaluates capability of international control system proposed by the West.

- He states that the system would be capable of detecting underground nuclear explosions from 10-20 KT if detonated in alluvium, but the detection threshold would be several-fold less for underground explosions in granite.

-- Regarding verification of a limited test ban, Nitze says that the U.S. would have to depend primarily on its own seismic detection system. He reviews the limited U.S. capability of detecting nuclear explosions in space but notes U.S. program underway to further develop this capability (the VELA HOTEL program for developing detection satellites). The first satellite is scheduled to be launched in Fall 1963. 
Oct: Cuban missile crisis. Provokes widespread calls for limits on testing and other stabilizing measures.

-- U.N. General Assembly passes two resolutions, one calling for a cessation of nuclear testing, and the other calling for negotiations of either a CTB or a limited test ban with a moratorium on underground tests.

Dec: In U.N., Soviets propose a CTB verified by unmanned, tamper-proof seismic stations. In parallel, Khrushchev writes to Kennedy, offers 2-3 inspections and 3 seismic stations to verify a CTB.

Kennedy replies, proposing 8-10 inspections and larger seismic network.

-- U.S. reduces offer to 7 inspections but issue remains unresolved. Kennedy had authorized negotiators to go to as few as 6 per year. Besides the dispute on inspections, there are remaining differences on the number of black boxes (Soviets could accept 3 on their territory, U.S. wants 8-10.) Differences also remain on inspection modalities and procedures for installing the black boxes.

$\underline{1963}$

April: After impasse on inspections goes unresolved, Khrushchev withdraws offer to accept limited number of inspections. Kennedy and Macmillan confer and then propose renewed tripartite CTB talks. Kennedy writes to Khrushchev, asking him to accept a high-level delegation to circumvent deadlocked negotiations in Geneva.

July: Khrushchev announces acceptance of concept of a limited test ban treaty in speech in East Berlin (July 2).

-- In July 10 speech at American University, Kennedy calls for relaxation in tensions between the superpowers and announces his preference for a CTB but willingness to consider a limited test ban treaty.

-- Kennedy dispatches Averell Harriman to negotiate a CTB if possible, or a limited ban. Khrushchev states unwillingness to pursue CTB with on-site inspection provision in initial meeting with Harriman. Negotiations for a Limited Test Ban Treaty (LTBT) begin (July 15).

Aug: $\quad$ LTBT signed in Moscow (August 5).

-- Preamble states that parties seek "to achieve the discontinuance of all test explosions of nuclear weapons for all time" and that they are "determined to continue negotiations to that end."

Oct: LTBT enters into force (October 10).

-- The LTBT effectively marks the end of CTB negotiations as concern diminishes about fallout and the arms race, though discussion continues in Geneva. 
-- Additionally, Kennedy agrees to grant several conditions to ensure support from the Joint Chiefs of Staff (JCS) for the LTBT, which he judges necessary for Senate ratification, but which effectively rule out any further near-term considerations of a CTB. These conditions include: (1) pursuit of a comprehensive and aggressive underground testing program; (2) maintenance of a modern nuclear weapons laboratory complex; (3) maintenance of the U.S. ability to resume atmospheric testing if Soviets do; and (4) continued pursuit of enhanced verification capabilities.

Nov: U.N. General Assembly passes resolution, taking note of the LTBT preamble and urging that negotiations for a CTB proceed in the ENDC "with a sense of urgency."

- U.S. and U.S.S.R. vote for resolution, but both clarify differences on verification. U.S. Ambassador Adlai Stevenson states that the U.S. still requires on-site inspection to "make it possible to dispel doubts as to the nature of certain seismic events." Soviet representative replies that U.S.S.R. "would not be prepared to accept any inspection inasmuch as they are not necessary."

-- Brazil proposes concept of banning underground tests that are already verifiable by national technical means and then lowering the threshold as future improvements are made. Neither U.S. nor Soviet Union endorse it.

Jan: ENDC takes up CTB issue, as superpowers restate differences on verification.

Air Force Technical Applications Center (AFTAC) begins operation of world wide network of seismic and intelligence gathering stations, known as AEDS (Atomic Energy Detection System).

Sept: Eight neutral nations of ENDC submit joint memorandum expressing regret that no progress has been made toward a CTB.

Oct: China conducts first test of nuclear device using U-235 at Lop Nor -- $20 \mathrm{KT}$.

\section{$\underline{1965}$}

Jan: Gilpatrick Committee delivers report to President Johnson, concluding that "It is unlikely that others can be induced to abstain from acquiring nuclear weapons if the Soviet Union and United States continue in a nuclear arms race." Report recommends lessened emphasis on nuclear weapons and pursuit of agreement on a broad range of arms control measures, including a CTB, nuclear weapons-free zones, and a fissile materials production cut-off.

June: National Security Action Memorandum 335 directs ACDA to develop an arms control program to prevent the spread of nuclear weapons.

July: In July 27 address to ENDC, Johnson advocates pursuit of a multilateral nonproliferation treaty. He states that U.S. goals are to limit the spread of nuclear weapons, work toward the effective limitation of U.S. and Soviet nuclear weapons and delivery systems, and to achieve a CTB. 
Representatives of India, United Arab Republic (U.A.R.), and Sweden attack NPT ideas offered by the U.S.

-- While sympathetic to the need to prevent the spread of nuclear weapons, Sweden argues that a CTB would be more useful for nonproliferation. These countries argue that any NonProliferation Treaty (NPT) cannot be one-side pledge by non-nuclear weapons states, but that superpowers must also give something up.

Sept: In ENDC, U.A.R. proposes a ban on tests greater than 4.75 on the Richter Scale, with enforcement by national technical means (NTM), and a moratorium on all underground tests while a technical group on verification techniques is pursued.

- Soviets support, while U.S. rejects. Eight neutral nations of ENDC issue memorandum stating that "measures to prohibit the spread of nuclear weapons should be coupled with or followed by tangible steps to halt the nuclear arms race and to limit, reduce, and eliminate the stocks of nuclear weapons and their means of delivery." In various statements, pursuit of a CTB is presented as the measure that neutral countries are willing to accept as a quid pro quo for an NPT.

Dec: U.N. General Assembly passes resolution urging all nations to suspend nuclear tests and for the ENDC to continue working for a CTB.

Jan: In address to ENDC, President Johnson states support for an NPT and extension of the LTBT to cover underground tests as long as this measure includes the number and type of inspections shown by science to be necessary to verify compliance.

Feb: Soviet Premier Kosygen states that Soviet Union "would agree to barring underground tests, but only on the basis of the use of national systems of detection."

Swedish representatives in ENDC take issue with U.S. position on technical grounds, questioning whether on-site inspections (OSI) would be of much use in uncovering clandestine tests.

-- They maintain NTM capabilities are already enough to deter potential evasion and propose challenge inspection scheme. Under this approach, if there were a suspected violation, and if the country on whose territory the event occurred could or would not provide a satisfactory explanation, the other side could issue a challenge for inspection. If the nation under suspicion would not invite inspectors from the other country, this could serve as grounds for abrogating the treaty.

-- U.S. responds that up to 45 seismic events per year in the Soviet Union could not be identified with current NTM. U.S. spokesman argues that a mandatory quota of inspections is preferable to challenge inspections, because of doubts that the Soviets would respond cooperatively to challenges, and because a treaty that depended on accusation for enforcement would not likely reduce international tensions. Soviets reject on grounds that the scheme represents international inspections in disguise. 
July: U.S. interagency debates merits of proposing a ban on tests above 4.75 or 5 on the Richter scale, verified with NTM, and without a moratorium on lesser tests, as a means of turning the "arms race down from the megaton level to the kiloton level."

-- Although DOD appears willing to accept this idea with a higher threshold, the prevailing arguments against it are: (1) such a ban would make little difference for threshold nuclear weapons states; and (2) in the absence of inspections, such a treaty would lead to international controversy and recriminations.

1967

Feb: Treaty of Tlatelolco signed in Mexico City, prohibiting acquisition, production, and testing of nuclear weapons by Latin American signatories.

June: China conducts first thermonuclear test $-3 \mathrm{MT}$.

$\underline{1968}$

April: Treaty of Tlatelolco enters into force.

July: Nuclear Nonproliferation Treaty (NPT) is signed (July 1). Preamble and Article VI contain linkage between superpower disarmament and nonproliferation.

Swedish submit report by seismic experts from 10 countries concluding that it is possible to distinguish large and medium earthquakes from nuclear explosions.

President Johnson's speech to ENDC omits specific reference to CTB for the first time in his tenure. Johnson states U.S. desire to begin talks with Soviets on reducing nuclear arms and delivery systems, reflecting increasing preoccupation with strategic offenses and defenses.

Aug: France conducts its first thermonuclear test at Fangataufa -- 2.6 MT.

1969

Jan: Nixon administration assumes office. Defense strategy and posture review places emphasis on pursuit or negotiations on strategic systems -- missiles and defenses.

Nov: Strategic Arms Limitation Talks (SALT) between the U.S. and U.S.S.R. begin. 
March: NPT enters into force (Miarch 5).

Dec.: U.S. underground test "Baneberry" releases radiation, resulting in 6-month shutdown of program and initiation of new safety measures.

1972: SALT I Interim Agreement and the Anti-Ballistic Missile Systems (ABM) Treaty are signed on May 26.

Feb-

Mar: Soviets privately propose scheme for CTB under which all testing would be banned, other nations would be asked to accede, and verification would be accomplished through NTM.

-- In response, U.S. raises problems of verification and difficulty of reaching agreement.

-- In March meeting between Soviet Foreign Minister Andrei Gromyko and U.S. Secretary of State Henry Kissinger held in Moscow, Soviets propose threshold test ban. U.S. responds favorably to this idea.

May: India explodes nuclear device in underground test in the Rajasthan Desert, allegedly for peaceful purposes.

July: After several weeks of negotiation, U.S. and Soviet Union sign bilateral Threshold Test Ban Treaty (TTBT), limiting the yield of underground nuclear weapons tests to $150 \mathrm{KT}$ and pledging the U.S. and U.S.S.R. to continue negotiations toward a CTB.

-- This scheme departs from earlier threshold test ban proposals in that it sets ceiling at 150 KT rather than a threshold measured in seismic magnitude. Treaty includes a protocol to designate geographic boundaries of test areas and to exchange other technical data, including geology of test sites and data from two calibration test shots at each test site (to be exchanged after ratification.)

-- Also, a separate agreement is reached that "one or two slight unintended breaches per year would not be considered a violation of the treaty" but would be cause for concern, and, on request, the subject for consultation. Treaty also makes explicit commitment of parties to negotiate a protocol covering peaceful nuclear explosions at "the earliest time possible." This protocol and the original treaty set to enter into force in 1976.

Sept: France explodes last atmospheric test at Mururoa. 
May: First NPT Review Conference (REVCON) Final Declaration calls upon nuclear weapons states to pursue a CTB and to limit the number of their underground nuclear weapons tests as a step to an agreement banning all nuclear weapons explosions.

$\underline{1976}$

May: U.S. and Soviet Union sign Peaceful Nuclear Explosions Treaty (PNET), limiting any individual nuclear explosion to $150 \mathrm{KT}$. President Ford delays ratification of TTBT and PNET. Many arms control proponents criticize TTBT and PNET as meaningless because threshold will do little to inhibit nuclear arms race or stem proliferation. (In following years, arms control critics begin to criticize agreements on grounds that they lack adequate enforcement provisions.)

Sept: Soviets table revised draft of CTB with provisions for voluntary inspections in U.N. General Assembly.

Jan: In his first press conference, newly elected President James Carter announces desire to achieve an end to nuclear testing, "immediately and permanently," reaffirming his 1976 campaign pledge.

Presidential Review Memorandum (PRM) 16 recommends pursuit of negotiations on CTB.

Feb: Soviets table CTBT draft in CCD, repeating offer for a CTB with a voluntary inspection regime.

Mar: Vance-Gromyko consultations on arms control issues. In an address at the United Nations, President Carter announces his intention to pursue a CTB.

July: U.S.-U.S.S.R.-UK consultations on CTB negotiations. Parties agree to begin formal negotiations in the fall.

Oct: $\quad$ Trilateral Negotiations begin in Geneva.

-- The initial U.S. and British goal is a universal treaty of unlimited duration banning all nuclear testing and going into effect as soon as the first 20 countries sign it. Western verification scheme includes mandatory on-site inspection, international seismic monitoring, and NTM.

-- Soviets are unwilling to consider an indefinite treaty until all nuclear powers become party to the agreement. The Soviets argue that PNEs should not be covered by the treaty, and that testing by other countries should be an explicit criterion for determining whether to extend the treaty. The Soviets also reject notion of mandatory OSI and again suggest the idea of voluntary challenge inspections. 
Nov: After 1st round of negotiations, Soviet General Secretary Leonid Brezhnev announces that Soviets will accept a moratorium on PNEs for the duration of a CTB and will defer on the issue of participation of France and China.

Jan-

May: U.S. reassesses position on verification and accepts in principle the proposition that voluntar, inspections can be as effective as mandatory inspections in deterring cheating.

In Geneva, Soviets propose a duration of 18-24 months. The treaty would then be extended only if other nuclear weapons powers acceded.

Panel under House Armed Services Committee begins hearings on the national security implications of a CTB. Directors of Los Alamos and Lawrence Livermore Laboratories testify that a CTB would adversely affect stockpile maintenance and reliability.

-- In its final report, released in Fall 1978, the panel concludes that a CTB would pose military risks that "cannot be ignored." It recommends, inter alia, that the administration not ban tests below yields of 10 kilotons, that it avoid a CTB until the completion of SALT II and MBFR, and that any future CTB include mandatory on-site inspection rights.

May-

Sept: Lab directors meet with Carter to argue against CTB. Carter decides to accept a fixed-term $\underline{\mathrm{CTB}}$, at first for five years, and later for three years. In latter case, the treaty would definitely end after three years and would require renegotiation and ratification for extension.

Carter and Gromyko agree to conclude SALT II agreement first and then pursue a CTB.

Feb: Iranian revolution and hostage crisis begins. Crisis further diverts attention of high level officials away from CTB issues. Also, loss of listening posts in Iran raises questions about U.S. ability to monitor arms control agreements.

May: U.K. Prime Minister Margaret Thatcher elected, resulting in a gradual shift away from U.K. leaderships' support of a CTB.

June: SALT II agreement signed.

Dec: Soviet Invasion of Afghanistan. 
Aug: Last Tripartite report to the Committee on Disarmament (CD) released.

-- The report indicates that the trilateral negotiations have produced agreement in principle on the major elements of a treaty. Negotiators have agreed to divide the treaty into several parts, including a main body, a protocol on peaceful nuclear explosions, and a separate verification agreement. They have also agreed in principle on the establishment of a Joint Consultative Commission to discuss compliance concerns and arrange inspections, and on the creation of a Committee of Experts to design and operate an international network of seismic stations after the treaty enters into force.

-- On substance, the tripartite delegations have reached agreement on a fixed-term treaty banning military and peaceful nuclear explosions, the right of parties to request on-site inspection, and the emplacement of national seismic stations (NSS) on the territory of each of the three negotiating powers.

-- However, by the end of 1980 , significant differences remain concerning the method of extending the ban, modalities for requesting and conduction inspections, and the numbers and locations of seismic stations, as well as arrangements for sharing seismic data from national seismic stations (NSS).

Sept: Second NPT Review Conference adjourns without agrsement on final document, due mainly to disagreement over CTB issue.

Oct: China conducts last atmospheric test $-200 \mathrm{KT}-1 \mathrm{MT}$.

Nov: Trilateral negotiations adjourn.

$\underline{1981}$

Jan-

July: First Reagan administration assumes office and conducts review on national security policy and testing issues.

-- In July, NSC decides that nuclear testing is indispensable to maintaining a credible nuclear deterrent and not to resume CTB negotiations. It also decides not to seek ratification of TTBT and PNET because they are unverifiable in their present forms, but that the U.S. should continue observance of $150-\mathrm{KT}$ threshold while seeking Soviet agreement to negotiate new verification protocols.

Oct: ACDA Director Eugene Rostow announces in U.N. General Assembly that it supports long-term goal of CTB, but that international conditions are not now propitious for continuing talks. 
$\underline{1982}$

July: President Ronald Reagan announces indefinite withdrawal from tripartite talks and states U.S. desire to renegotiate verification protocols for the TTBT and PNET.

Senate considers resolution calling on the administration to negotiate a CTB (co-sponsored by 21 senators.)

Oct: Administration announces that effective verification of the TTBT and PNET requires direct hydrodynamic yield measurements taken by U.S. personnel at the site of each nuclear detonation.

$\underline{1983}$

Mar: Soviets reject U.S. proposal to renegotiate TTBT and PNET verification protocols, stating that TTBT does not need fixing. Soviets call for ratification of treaties and negotiation of CTB.

May: House passes resolution calling for freeze on production, deployment, and testing of nuclear weapons, 278-149. Senate votes measure down in 1983 and 1984.

$\underline{1984}$

Jan: First Reagan administration report on Soviet noncompliance with existing arms control agreements. Report states that Soviets have "likely violated" the TTBT. U.S. spokesmen express

fear that Soviets could gain unilateral military advantage through the introduction of high-yield warheads, while U.S. designs remain constrained to high-yield technology tested prior to 1976.

May: Sweden, India, Mexico, Tanzania, Greece, and Argentina call for freeze on testing, production, and deployment of nuclear weapons.

June: In address to Conference on Disarmament, Japanese Foreign Minister Abe states that, if a CTB cannot be achieved in one stroke, the superpowers should explore a multilateral, step-by-step approach of setting a threshold at a yield considered to be verifiable and then lowering the threshold as verification capabilities improve.

Senate passes amendment to Defense Authorization Act (77-22), expressing the Senate's sense that the President should request the advice and consent to the ratification of the TTBT and PNET, submit a report containing any plans the President may have to negotiate supplemental verification procedures, and propose the resumption of CTB negotiations.

Sept: In a speech to the U.N. General Assembly, President Reagan proposes that "we find a way for Soviet experts to come to the United States nuclear test site, and for ours to go to theirs, to measure directly the yields of tests of nuclear weapons." 
Jan: Senator Gary Hart calls for a moratorium on testing and resumption of CTB negotiations.

Mikhael Gorbachev becomes Soviet Secretary General.

July: U.S.S.R. announces nuclear testing moratorium from August 6 to the end of the year, invites U.S. to follow suit, proposes the resumption of CTB negotiations, and calls for the ratification of the TTBT and PNET.

Sept: Third NPT Revcon final document reaffirms LTBT and NPT language calling for CTB. Final document states,

The Conference except for certain States...deeply regretted that a comprehensive multilateral Nuclear Test Ban Treaty...had not been concluded so far and, therefore, called on the nuclear-weapon States...to resume trilateral negotiations in 1985 and called on all the nuclearweapon States to participate in the urgent negotiation and conclusion of such a Treaty as a matter of the highest priority in the Conference on Disarmament.

At the same time, the Conference noted that certain States Party to the Treaty, while committed to the goal of an effectively verifiable comprehensive Nuclear Test Ban Treaty, considered deep and verifiable reductions in existing arsenals of nuclear weapons as the highest priority...

Oct: In the first of several joint letters to the Soviet Union and United States, heads of state from Argentina, Mexico, Sweden, India, Tanzania, and Greece appeal to President Reagan and General Secretary Gorbachev for a cessation of nuclear testing and for nuclear disarmament. Mexico also floats proposal of amending the LTBT to prohibit underground nuclear tests.

Nov: First Gorbachev-Reagan Summit in Geneva. Gorbachev announces at the end of the summit that if the U.S. and Soviets can agree to end nuclear testing, "there will be absolutely no problems on our side with regard to verification."

Dec: Gorbachev letter to Reagan committing Soviet Union to accepting OSI as a part of any CTB.

President Reagan's reply states that a CTB is a long-term objective, in the context of deep and verifiable arms reductions, improved verification capabilities, greater balance in conventional forces, and "at a time when a nuclear deterrent is no longer essential."

1986

Jan.: Gorbachev extends moratorium to March 31. He announces comprehensive arms control proposal which includes an immediate moratorium on nuclear testing and a resumption of CTB negotiations. 
Feb.: House passes resolution (268-148) urging Reagan to resume CTB negotiations and seek advice and consent to ratification of the TTBT and PNET.

Mar: In letter to Gorbachev, President Reagan describes the CORRTEX (hydrodynamic yield of nuclear explosions) system, invites Soviet experts to Nevada to observe its operation, and proposes negotiations on new verification measures for TTBT and PNET.

In a television broadcast, Secretary General Gorbachev reaffiıns that Soviet moratorium will last beyond March 31 if the U.S. does not test. He states that Soviets will resume testing if U.S. fails to join moratorium and proposes a summit with Reagan to discuss a test ban.

Apr: Gorbachev rejects Reagan's invitation to Nevada and proposes a meeting without preconditions to discuss Soviet CTB proposal and the U.S. verification scheme.

Disaster at Chernobyl power reactor (April 8).

May: Soviets extend moratorium until August 6 (announced by Gorbachev in speech on the Chernobyl nuclear plant catastrophe).

Agreement between the Soviet Academy of Sciences and the U.S.-based Natural Resources Defense Council to establish seismic stations near each country's nuclear test sites.

June: Gorbachev sends message to Reagan on nuclear power safety, with offer to meet anywhere to discuss a CTB. Soviets also agree to experts meetings proposed by Reagan in April.

Nuclear Testing Experts Meetings convene, lasting for six rounds (from June 25, 1986 to 20 July 1987).

Aug: House passes amendment (234-155) to FY 87 Defense Authorization bill prohibiting funds for nuclear tests greater than $1 \mathrm{KT}$ for a period of one year if Soviets agree to same limit and incountry seismic monitoring.

Soviets extend moratorium until January 1, 1987.

Sept: In a September 22 address to the U.N., Reagan notes ongoing experts talks, states U.S. readiness to move forward on TTBT and PNET ratification once agreement is reached on improved verification procedures, and says "in association with a program to reduce and ultimately eliminate all nuclear weapons, we are prepared to discuss ways to implement a step-by-step parallel program of limiting and ultimately ending nuclear testing."

In September 23 press statement, Reagan explains that the U.S. needs to test to maintain credible nuclear deterrent.

Oct: Deal struck between administration and Congress in which President Reagan promises to submit the PNET and TTBT for ratification if the House's $1 \mathrm{KT}$ test limit provision is dropped. 
-- Reagan pledges that once PNET and TTBT are ratified, he will propose that the U.S. and Soviet Union engage in negotiations "on ways to implement a step-by-step program...limiting and ultimately ending nuclear testing."

\section{Reykjavik Summit (October 10-12).}

-- At the end of the summit, Gorbachev states that Soviets have requested talks on banning nuclear explosions immediately, and hints at willingness to examine the issue of the ceilings on nuclear explosion yields, the number of explosions per year, and the fate of the TTBT and PNET as steps toward the eventual goal of a CTB.

-- In October 13 reply, NSC Advisor Admiral John Poindexter announces that U.S. and Soviets have agreed to begin negotiations to improve verification procedures and not to move beyond this first agenda item until it is resolved successfully. Upon completion of this first step, both sides would then move to negotiating further limits on nuclear testing, "with the ultimate goal being a comprehensive test ban, as we reach the point that we no longer have to rely on strategic nuclear weapons for deterrence..."

Nov: Secretary of State George Shultz and Soviet Fore'gn Minister Eduard Shevardnadze meet in Vienna (Nov. 5-6).

- In separate press conferences, the two ministers provide different interpretations of their discussions on nuclear testing issues. Shevardnadze states that full-scale bilateral negotiations "are to begin on the complete cessation of nuclear tests." In the course of these treaties, consideration will be given to verification, lowering the threshold and yield and reducing their number, and the TTBT and PNET.

- Schultz announces that agenda for negotiations will be first to resolve verification issues, and then to proceed with the reduction and elimination of nuclear weapons to address "further stepby-step limitations on testing, leading ultimately to the elimination of nuclear testing."

Dec: Soviet government releases proposal for immediate, full-scale negotiations on a CTB, "in any composition and in any forum..." This statement conveys that the Soviets will resume testing after first U.S. test in 1987. But if the U.S. ends nuclear tests, the Soviet Union will follow suit.

Jan: Reagan requests Senate advice and consent to ratification of the TTBT and PNET, subject to the condition that the President will not proceed wiih ratification until he has certified that the U.S. and U.S.S.R. have concluded additional verification agreements.

Feb: U.S. test (February 3); Soviet testing resumes on February 26, first test in 18 months.

June: Soviets present new proposals for international body to monitor a test ban and indicate willingness to open test sites to mandatory inspection. 
Sept: U.S. and U.S.S.R. announce in joint communique agreement to conduct stage-by-stage nuclear testing negotiations. Talks first to discuss verification protocols for TTBT and LTBT, then pursuit of intermediate testing limits, and finally a CTB.

Senate rejects Kennedy-Hatfield amendment for cessation of tests greater than $1 \mathrm{KT}$ for two years (allowing for two reliability tests of not greater than $15 \mathrm{KT}$ each year) if the Soviets reciprocate and allow in-country seismic monitoring.

Nov: U.S. and Soviet Union begin first round of Nuclear Testing Talks (NTT), November 9-20, focusing exclusively on TTBT and PNET verification issues. At conclusion of round, U.S. and Soviets announce that delegations will visit each other's nuclear test sites in January 1988 .

Dec: Washington Summit: U.S. and Soviet Union sign Intermediate-Range Nuclear Force (INF) Treaty and agree to the Joint Verification Experiment (JVE), allowing each side to monitor a nuclear test at the other's test site.

Jan: U.S. nuclear testing experts visit Semipalatinsk, January 8-15. Joint communique states that the scientists gained familiarity with the work and organizations at the Soviet test site and tested different techniques to estimate the yield of nuclear explosions.

-- Ianuary 24-30, Soviet experts visit Nevada test site. Experts are briefed on organization and cperations of the site and the U.S. demonstrates CORRTEX statements.

Feb: Round II of the Nuclear Testing Talks convene in Geneva.

Mar: On March 9, U.S. and Soviet delegations table separate draft verification protocols. U.S. draft allows routine use of on-site hydrodynamic yield measurements (CORRTEX) to verify compliance with the TTBT. Soviets staie that CORRTEX technology must be demonstrated through Joint Verification Experiment.

U.S. releases report (March 18) to Congress on Soviet compliance with arms control agreements, reaffirming previous conclusions that "Soviet nuclear testing activities for a number of tests constitute a likely violation of legal obligations under the TTBT."

On March 31, U.S. delegation tables a draft verification protocol allowing use of CORRTEX system to verify the PNET. U.S. delegation leader also notes that, because of Soviet insistence that the JVE is necessary before they can finalize the TTBT protocol, the U.S. negotiators will make necessary arrangements for the JVE as quickly as possible.

Apr: House passes third consecutive amendment to defense authorization bill to halt all tests above 1 $\mathrm{KT}$ if the Soviets adhere to the same limit and permit in-country seismic monitoring. Amendment is again dropped in conference committee. 
U.S. experts arrive April 12 at Soviet test site as part of JVE and begin to transport equipment for observing Soviet test and measuring it with CORRTEX system. Soviet experts arrive in Nevada to observe test preparations.

May: Moscow Summit (May 29-June 1). Reagan and Gorbachev order negotiators to complete TTBT and PNET verification protocols as soon as possible after the JVE has been completed and the results analyzed. Shultz and Shevardnadze finalize agreement on JVE procedures and schedule.

June: Preparations for JVE in both U.S. and U.S.S.R. continue. At conclusion of Round II of NTT in Geneva, both sides express optimism that an agreement on verification protocols for the TTBT and PNET is close at hand.

Aug: Six LTBT signatories propose a conference to amend the LTBT to prohibit all nuclear weapons testing.

- On August 5, the 25th anniversary of the LTBT's signing, Indonesia, Mexico, Peru, Sri Lanka, Venezuela, and Yugoslavia submit a proposed amendment to the treaty's original signatories (U.S., U.K., and U.S.S.R). Under LTBT provisions, the depositary governments must convene a conference to consider an amendment if at least one-third of the signatories request such a meeting.

U.S. test of JVE (Operation "Kearsarge") is conducted August 17 at Nevada Test Site, with 41 Soviet observers present to measure the yield using to Soviet-developed hydrodynamic methods.

Round III of NTT convenes August 28.

Sept: U.S.S.R. JVE test (Operation "Shagan") conducted at Semipalatinsk. 45 U.S. observers measure yield with CORRTEX system.

Oct: U.S. and Soviet experts exchange hydrodynamic yield data obtained during tests.

Nov: U.S. and Soviet delegations in Geneva reach agreement in principle on text of new PNET verification protocol. Work shifts to TTBT protocol.

Jan: Bush administration assumes office and begins a comprehensive review of U.S. defense and arms control policies.

Feb: Soviet test at Semipalatinsk releases radioactive gas, resulting in international condemnation and calls for a CTB.

Apr: LTBT parties who proposed amending LTBT to ban all nuclear weapons tests announce support of $1 / 3$ of all LTBT signatories for this idea.

-- Under the terms of the treaty, this requires the depository governments to organize a conference to consider an amendment. Any amendment to the LTBT must be approved by a 
majority of all parties to the treaty, including all three original signatories. U.S. vows that it will veto any attempt to amend the LTBT.

May: French President Mitterand announces that France will implement a moratorium if other nuclear weapons states (minus China) do not test as well.

Soviets conduct last test before a 12 -month moratorium.

23 Senators and 142 House members urge President Bush to adopt a step-by-step approach for phasing out all nuclear testing by 1995 .

June-

Aug: $\quad$ Round IV of NTT (June 26-August 8).

Sept: Shevardnadze-Baker Ministerial at Jackson Hole, Wyoming (September 22-23). Joint communique announces agreement on a verification measures for the TTBT and PNET that include hydrodynamic measurement, seismic stations, and on-site inspections.

Leadership Summit of Non-Aligned nations release statement that a CTB is "absolutely essential for the preservation of the nonproliferation regime embodied in the Nonproliferation Treaty."

Oct-

Dec: Round V of NTT.

Jan: Bush policy statement on January 15 declares that the administration has not identified further limits on nuclear testing that would be in the U.S. national interest.

-- This document states that administration views a CTB as a long-term objective that would be possible "when we do not need to depend on nuclear deterrence." Round VI of NTT begins on same day.

Feb: DOE report to Congress argues that 10 more years of testing are necessary to determine whether the U.S. nuclear deterrent could be maintained under agreement beyond TTBT.

76 House members urge Bush to reverse position on nuclear testing talks.

May: Round VI of NTT adjourns.

The House Armed Services Committee establishes a panel to examine and report on nuclear warhead safety issues in response to press reports of the potential dangers of plutonium dispersal in the event of an accident or handling mishap. 
-- Panel is to be chaired by Sidney Drell, deputy director of the Stanford Linear Accelerator Center. Other members are Charles H. Townes of the University of California at Berkeley and Dr. John S. Foster, head of the Defense Science Board.

June: At Washington Summit (May 30-June 3), U.S. and Soviet Union sign new verification protocols to TTBT and PNET.

Sept: Fourth NPT Revcon fails to reach consensus on a final document due to deadlock over CTB.

Senate approves TTBT and PNET verification protocols.

Oct: $\quad$ Supreme Soviet ratifies TTBT and PNET verification protocols.

Soviets conduct first test in a year.

Dec: Drell panel releases its findings on December 19.

-- The report concludes that enhanced safety should become the top priority of the U.S. nuclear weapons program. The panel recommends equipping all weapons with Enhanced Nuclear Detonation Safety Systems (ENDS); building all nuclear weapons for deployment on aircraft with insensitive high explosives (IHE) to reduce the chance that an accident will lead to widespread plutonium contamination; and reviewing the decision to retain weapons systems such as the Trident II submarine-launched ballistic missiles (SLBM), which does not use IHE or fire-resistant plutonium pits, and which uses a high-energy propellant stage located next to the warhead. During their testimony, Drell and Foster call for a thorough analysis of existing and future warhead designs with computer simulations and actual experiments and tests.

1991

Jan: LTBT Amendment Conference convenes in New York from January 7-18 to consider whether to amend the treaty to prohibit underground nuclear explosions. The meeting was called by 40 non-nuclear weapons states over the objections of the U.S and U.K.

-- No agreement on a CTB is reached, in part due to U.S. and U.K. opposition. But the parties vote overwhelmingly (75-2) in favor of continuing the conference at a later date, with 19 abstentions (including Canada, Israel, and several East and West European countries.) The Soviet Union votes in favor of continuing conference.

-- In general discussions, overwhelming majority of 60 countries making statements argue in favor of a near-term CTB, citing the end of the Cold War and the test ban's link to stopping the arms race and promoting nonproliferation. Six nonaligned conference sponsors table two draft amendments -- (1) a new Article (VI) stating that any protocols annexed to the LTBT constitute an integral part of the treaty; and (2) Protocol II, which deals with verifying a CTB (including treaty institutions, operating procedures, and annexes on a permanent global monitoring network, local monitoring stations, and on-site inspection.) 
-- Although supporting a CTB, many countries oppose amending the LTBT as a means to that end, favoring instead the negotiation of a CTB in the Conference on Disarmament. However, because the $\mathrm{CD}$ has no mandate to negotiate a CTB and can only discuss issues, many representatives acknowledge need for further discussion in the LTBT conference until the CD's mandate is expanded.

-.- On the issues of whether and when the Conference should reconvene, U.S. expresses the desire for no final statement whatsoever. Several non-aligned nations propose language committing the LTBT signatories to gather again "no later than September 1993" and calling for an intercessional working group to address CTB verification issues. Several Western countries seek to remove any specific date for reconvening the conference and instead propose a final Conference statement that instructs the President of the Conference "to conduct consultations with a view to achieving progress on those issues and resuming the work of the Conference at an appropriate time."

-- In the final compromise, the non-aligned agree to remove reference to any specific date in the final statement and to leave the reconvening of the conference in the hands of the Conference President Ali Alatas of Indonesia.

Feb: In the Bush administration's response to the Drell panel findings, Assistant Secretary of Energy for Defense Programs Richard Claytor testifies before the House Armed Services Committee Panel on the U.S. Department of Energy's (DOE's) Defense Nuclear Facilities.

-- Claytor states that DOE "fully supports the goal of having ENDS and IHE on aircraft systems," but reveals that warheads without ENDS and IHE will not be completely retired until the year 2000. He also notes DOE support for the addition of fire-resistant plutonium pits to weapons on aircraft. He cautions that the W-61 (a gravity bomb deployed on aircraft) and W-80 (carried by air-launched cruise missiles) warheads, which do use IHE, will require costly upgrades for fire-resistant pits. Claytor also says that DOE supports the panel's proposal for, and is already involved in, a review of the Trident II weapons system.

Aug: On August 3, Congress passes the Hatfield-Exon-Mitchell Amendment, which establishes an interim testing moratorium through July 1, 1993.

-- It states that "no underground test of nuclear weapons may be conducted by the United States after September 30,1996, unless a foreign state conducts a nuclear test after this date." The law requires the President to submit "a plan for achieving a multilateral comprehensive ban" on testing by that date.

-- Between 1993 and 1996, the President must report to Congress on any planned tests and the status of U.S. efforts to negotiate a CTB. Under the legislation, the U.S. may carry out up to 12 tests for safety and reliability to incorporate additional safety features into the warheads the U.S. plans to retain after 1996, if the President certifies that the tests are "necessary in order to ensure the safety" of those warheads. Three other tests could be conducted with the United 
Kingdom. The law prohibits resumption of testing until 90 legislative days after a testing report is submitted to Congress.

-- President Bush signs the law into effect in early October.

Sept-

Nov: Clinton declares his commitment to a CTB expressed the 1992 Presidential campaign, stating that he supports a phased approach and noting that a CTB "would strengthen our vital efforts to stop the spread of nuclear weapons to other countries."

Russian President Boris Yeltsin states that Russian test moratorium will extend through July 1993.

$\underline{1993}$

Apr: During the Vancouver Summit with Russia, Clinton reaffirms his campaign pledge to pursue a CTB. Clinton also announces the start of a consultative process with Russia, China, and U.S. allies aimed at starting CTB negotiations.

July: On July 3, President Clinton announces the extension of the testing moratorium until September 1994 , as long as no other nation tests. He states that next year, the "no-first test" policy will be reviewed. If another nation tests in the meantime, Clinton will direct the DOE to prepare for additional tests.

Oct: China conducts its first nuclear test in 12 months at Lop Nor.

-- The White House releases a written statement that the administration "deeply regrets" the tests and urges China to refrain from any more. The statement also urges China to join other nuclear weapons states in negotiating a global CTB, noting that Clina has defied appeals from more than 20 nations to call off the test.

-- According to the White House statement, President Clinton directed the Department of Energy to take the necessary actions to enable the U.S. to conduct nuclear tests in 1994, "provided the notification and review conditions of the Hatfield-Exon-Mitchell Amendment are met in the spring of 1994." The statement notes that the decision on whether to resume testing will be based on "U.S. national security interests, taking into account 1) the contribution that further tests would make to improving the safety and reliability of the U.S. arsenal in preparation for a CTB; 2) the extent to which China and others have responded to the U.S. appeal for a global moratorium on testing; 3 ) progress in the CTB negotiations; and 4) the implications of further tests on our [U.S.] non-proliferation objectives."

-- China issues a statement that says, "History has shown that a conditional 'moratorium' designed to maintain nuclear superiority while refusing to renounce nuclear deterrence and commit oneself to complete prohibition and thorough destruction of nuclear weapons is of extremely limited significance." 


\section{CTB CHRONOLOGY, 1945-1993}

1945: In July, U.S. conducts first nuclear test ("TRINITY" explosion) at Alamagordo Air Base -- 19 KT.

U.S. drops atomic bombs on Hiroshima and Nagasaki (August).

1946: U.S. proposes Baruch Plan in June to establish nuclear disarmament and international control over all nuclear activities. Soviets reject.

1949: U.S.S.R. explodes first atomic bumb, "Joe 1," in August -- 10-20 KT.

1952: Britain explodes first atomic bomb at Monte Bello Islands (near Australia) in October.

In November, U.S. explodes its first full-scale, 62-ton thermonuclear device "Mike" (using liquid tritium and deuterium) at Enewetak Atoll -- $10 \mathrm{MT}$.

1953: U.S.S.R. explodes one-stage fission/fusion bomb "Joe 4" using dry hydrogen isotopes -- $200 \mathrm{KT}$.

1954: U.S. explodes first full-scale thermonuclear bomb "BRAVO" at Bikini Atoll - 15 MT.

-- Explosion contaminates wide areas in Pacific and exposes 236 residents of Marshall Islands and 28 Americans to radiation.

-- Press coverage of BRAVO triggers national and international scrutiny of dangers of fallout and calls for test ban.

1956: Adlai Stevenson, Democratic Presidential candidate, proposes ban on H-bomb tests in speech to American Society of Newspapers (April 21).

-- Eisenhower replies (April 25) that H-bombs are necessary element of missile-based nuclear deterrent.

1957: Britain conducts first thermonuclear test at Christmas Islands in May.

In August, President Eisenhower proposes suspension of nuclear testing for up to two years, linked to a fissionable materials production cutoff). Soviets reject this linkage.

1958: U.S.S.R. announces unilateral moratorium on all nuclear tests if Western nations also stop; does not enter into effect until several months later on March 31.

On April 28, Eisenhower proposes a Conference of Experts to examine how compliance with a test ban could be verified. Soviets agree.

-- After convening in July, the Conference of Experts releases its findings on August 21, concluding that a control system composed of 160-170 in-country monitoring stations could detect 
and identify atmospheric explosions above 1-KT threshold and underground explosions greater than $5 \mathrm{KT}$.

On basis of Experts' report, Eisenhower proposes on August 22 to begin tripartite negotiations with the U.K. and U.S.S.R. to end nuclear tests and a test moratorium for the first year of talks, if Soviets also do not test. Soviets agree.

-- U.S., U.S.S.R., and Britain begin Tripartite negotiations on a CTB in Geneva on October 31 in the Conference on the Discontinuance of Nuclear Weapons Tests. Eisenhower states that U.S. would extend moratorium to end of the year. Soviet Union announces that it will not test as long as "Western powers" follow suit.

1959: U.S. announces data from "HARDTACK II" underground tests conducted just before the moratorium. It reveals that detection and identification of underground tests is more difficult than depicted by the original Experts' report.

-- This discovery reopens debate on test ban within the Eisenhower demonstration.

-- In ongoing Tripartite negotiations in Geneva, Soviets reject Hardtack II data and insist that negotiating parties are bound by earlier findings. Eisenhower writes to Khrushchev on April 13, proposing a ban on atmospheric tests under the altitude of $50 \mathrm{~km}$ as an interim measure.

1960: During continuing Tripartite negotiations, U.S. proposes ban on atmosphere testing, tests underwater, and underground tests greater than 4.75 on the Richter scale, with monitoring by onsite inspections. Signatories would also establish a joint seismic research program to discussion lowering of underground threshold.

On February 13, France detonates its first nuclear weapon in Sahara Desert -- 60-70 KT.

Soviets offer counter proposal in March to add a ban on all tests in space and a 4-5 year, unsupervised moratorium on tests below 4.75 on the Richter scale. U.S. and U.K. agree in principle to accept a moratorium of agreed duration on low-yield underground tests, but insist on means of international supervision.

U.S. U-2 is shot down over Sverdlosk on May 1, ruining chances for 4-Power Paris summit to resolve remaining testing issues. Negotiations in Geneva continue, but progress all but ceases.

1961: President Kennedy orders review of U.S. position on testing to determine what concessions could be offered to meet Soviet objections, while not impairing U.S. security.

In April, the Tripartite negotiations reconvene, and the U.S. and U.K. table a complete draft treaty for the first time that incorporates areas of agreement from previous negotiations. The new draft proposes a limited test ban on all but underground tests less than 4.75 on the Richter, a 3year moratorium on such tests while verification research continues, and an annual quota of inspections depending on the number of seismic events in the U.S.S.R. (U.S. proposes 12-20 per year). 
On September 1, Soviets begin test series, with 30 atmospheric blasts in 60 days. (U.S.S.R. explodes nuclear device over Novaya Zemlya -- $58 \mathrm{MT}$.)

In November round of Tripartite negotiations in Geneva, Soviets table draft test ban, with verification details to be worked out after treaty. U.S. and Britain reject.

1962: In January, Tripartite negotiations end in deadlock and adjourn indefinitely.

U.S. resumes atmospheric testing in April with operation "DOMINIC," a series of 40 atmospheric tests over 6 months.

Cuban missile crisis (October).

In the U.N., the Soviets propose a CTB verified by unmanned, tamper proof seismic stations in December.

-- In parallel, Khrushchev writes to Kennedy, offers 2-3 inspections and 3 seismic stations. Kennedy replies, proposing 8-10 inspections and larger seismic network.

1963: Khrushchev withdraws offer on inspections in April.

Kennedy writes to Khrushchev, asking him to accept a high-level delegation to circumvent deadlocked negotiations in Geneva. Khrushchev announces acceptance of concept of a limited test ban treaty in speech in East Berlin (July 2).

-- Kennedy dispatches Averell Harriman to negotiate a CTB if possible, or a limited ban. Khrushchev states unwillingness to pursue CTB with on-site inspection provision in initial meeting with Harriman.

-- Negotiations for an LTBT begin on July 15. LTBT signed in Moscow on August 5 . LTBT enters into force on October 10.

1964: Eighteen Nation Disarmament Committee takes up CTB issue, as superpowers restate differences on verification.

China conducts first test of nuclear device using U-235 at Lop Nor $-20 \mathrm{KT}$.

1967: Treaty of Tlatelolco is signed in Mexico City, prohibiting acquisition, production, and testing of nuclear weapons by Latin American signatories.

China conducts first thermonuclear test.

1968: Nuclear Nonproliferation Treaty (NPT) is signed on July 1.

-- Preamble and Article VI contain linkage between superpower disarmament and nonproliferation, taken by neutral countries to mean the eventlial pursuit of a CTB. 
1974: India explodes nuclear device in underground test in the Rajasthan Desert, claiming it was for peaceful purposes (May).

In July, U.S. and Soviet Union sign bilateral Threshold Test Ban Treaty (TTBT), which limits the yield of underground nuclear weapons tests to $150 \mathrm{KT}$ and pledges the U.S. and U.S.S.R. to undertake negotiations toward a CTB. The TTBT is not set to enter into force until 1976, when the U.S. and U.S.S.R. are to have completed negotiations on the limitation of peaceful nuclear explosions.

1975: First NPT Review Conference calls for a CTB (May).

1976: In May, U.S. and U.S.S.R. sign Peaceful Nuclear Explosions Treaty (PNET), limiting any individual nuclear explosion to $150 \mathrm{KT}$.

-- President Ford submits the TTBT and PNET to the Senate for advice and consent on July 29, but the Senate postpones action until after the November 1976 presidential and congressional elections.

1977: After President Carter assumes office, he does not seek ratification of the TTBT and PNET, and instead he announces his intention to pursue negotiation of a CTB.

Trilateral negotiations on a CTB between the U.S., U.S.S.R., and U.K. begin in Geneva in October.

1978: U.S. reassess its position on verification of a CTB and accepts in principle notion that voluntary inspections will deter cheating.

-- In early summer, Carter decides to accept a fixed-term CTB.

In September, Carter and Gromyko agree to conclude SALT II agreement first and then pursue a CTB.

1979: Iranian revolution and hostage crisis begins (Feb). Soviet Invasion of Afghanistan (Dec).

1980: Second NPT Review Conference adjourns without agreement on final document, due mainly to disagreement over CTB issue (Sept).

1981: In July, NSC decides that nuclear testing is indispensable to maintaining a credible nuclear deterrent and not to resume CTB negotiations.

-- It also decides not to seek ratification of TTBT and PNET because they are unverifiable in their present forms, but that the U.S. should continue observance of $150 \mathrm{KT}$ threshold while seeking Soviet agreement to negotiate new verification protocols.

1982: Reagan announces indefinite withdrawal from Tripartite talks on CTB and U.S. desire to renegotiate verification protocols for the TTBT and PNET (July). 
1983: Soviets reject U.S. proposal to renegotiate TTBT and PNET verification protocols, stating that TTBT does not need fixing.

1984: First Reagan administration report on noncompliance by the Soviet Union with existing arms control agreements (Jan) stating that Soviets have "likely violated" the TTBT.

In September speech to the U.N. General Assembly, Reagan proposes exchange of experts to measure yields of tests of nuclear weapons.

1985: In July, U.S.S.R. announces nuclear testing moratorium from August 6 to the end of the year, invites U.S. to follow suit, proposes the resumption of CTB negotiations, and calls for the ratification of the TTBT and PNET.

In September, Third NPT Revcon final document reaffirms LTBT and NPT language calling for CTB.

- Final document notes that most of the NPT parties believe that a CTB should be negotiated "as a matter of the highest priority," but that other parties, while committed to the long-term goal of achieving a verifiable CTB, view deep and verifiable reductions of nuclear weapons as the most urgent priority.

November Geneva Summit, Gorbachev - Reagan.

-- Gorbachev announces at the end of the summit that if the U.S. and Soviets can agree to end nuclear testing. "there will be absolutely no problems on our side with regard to verification."

-- December Gorbachev letter to Reagan commits Soviet Union to accepting OSI as a part of any CTB.

-- Reagan's reply: CTB is long-term objective, in context of deep and verifiable arms reductions, improved verification capabilities, greater balance in conventional forces, and "at a time when a nuclear deterrent is no longer essential."

1986: Gorbachev extends moratorium to March 31 .

In March letter to Gorbachev, Reagan describes the CORRTEX system, invites Soviet experts to Nevada to observe its operation, and proposes negotiations on new verification measures for TTBT and PNET.

In June, Gorbachev sends message to Reagan on nuclear power safety, with offer to meet anywhere to discuss a CTB. Soviets also agree to experts meetings.

Nuclear Testing Experts Meetings convene, lasting for six rounds (from June 25, 1986 to 20 July 1987).

1987: In January, President Reagan submits the TTBT and PNET for advice and consent on ratification, asking the Senate to examine additional verification measures which the Soviet Union would have to accept as a condition for the treaties entering into force. 
In September, U.S. and U.S.S.R. announce in joint communique agreement to conduct stage-bystage nuclear testing negotiations.

-- Talks first to discuss verification protocols for TTBT and LTBT; then pursuing of intermediate testing limits; and finally, a CTB.

-- U.S. and Soviet Union begin first round of Nuclear Testing Talks (November 9-20), focusing exclusively on TTBT and PNET verification issues. At conclusion of round, U.S. and Soviets announce that delegations will visit each other's nuclear test sites in January 1988.

December Washington Summit: U.S. and Soviet Union sign INF Treaty and agree to the Joint Verification Experiment, allowing each side to monitor a nuclear test at the other's test site.

1988: Six LTBT signatories propose a conference to amend the LTBT to prohibit all nuclear weapons testing. U.S. opposes.

U.S. test of JVE (Operation "Kearsarge") is conducted August 17 at Nevada Test Site, with 41 Soviet observers present to make measure the yield using to Soviet-developed hydrodynamic methods.

U.S.S.R. JVE test (Operation "Shagan") conducted at Semipalatinsk in September. 45 U.S. observers measure yield with CORRTEX system.

1989: In May, French President Francois Mitterand announces that France will implement a moratorium if other nuclear weapons states (minus China) do not test.

Soviets conduct last test in May before beginning a 12-month moratorium.

Shevardnadze-Baker Ministerial at Jackson Hole, Wyoming (September 22-23). Joint communique announces agreement on a verification measures for the TTBT and PNET that include hydrodynamic and seismic measurements and on-site inspections.

1990: Bush policy statement on January 15 declares that administration has not identified further limits on nuclear testing that would be in the U.S. national interest.

-- States that administration views a CTB as a long-term objective that would be possible "when we do not need to depend on nuclear deterrence."

-- Round VI of NTT begins on same day.

At Washington Summit (May 30-June 3), U.S. and Soviet Union sign new verification protocols to TTBT and PNET.

Fourth NPT Revcon in September fails to reach consensus on a final document due to deadlock over CTB.

1991: LTBT Amendment Conference convenes in New York from January 7-18 to consider whether to amend the treaty to prohibit underground nuclear explosions. 
-- No agreement on a CTB is reached, in part due to U.S. and U.K. opposition. But the parties vote overwhelmingly (75-2) in favor of continuing the conference at a later date. Soviet Union votes in favor of continuing conference.

1992: On August 3, Congress passes the Hatfield-Exon-Mitchell Amendment, which establishes an interim testing moratorium through July 1, 1993.

-- President Bush signs the law into effect in early October.

1993 During the April Vancouver Summit with Russia, Clinton reaffirms his campaign pledge to pursue a CTB. Clinton also announces of the start of a consultative process with Russia and other U.S. allies aimed at starting CTB negotiations.

On July 3, Clinton announces the extension of the testing moratorium until September 1994, as long as no other nation tests.

-- He states that next year, the "no-first test" policy will be reviewed. If another nations tests in the meantime, Clinton will direct the DOE to prepare for additional tests.

In early October, China conducts its first nuclear test in 12 months at Lop Nor.

-- White House releases written statement that the administration "deeply regrets" the tests and urges China to join other nuclear weapons states in negotiating a global CTB. Statement indicates that Clinton has directed the DOE to take the necessary actions to enable the U.S. to ccnduct nuclear tests in 1994, but that decision to resume testing will not be made until a future date. 


\section{A Note on Sources}

The principal purpose of this chronology is to provide a general and selective historical background on comprehensive testing negotiations since the early 1950s. It is neither an official document nor a definitive historical account. The chronology is based almost exclusively on secondary source material, which is summarized below. The author is indebted to Paul Brown, Alan Greb, Warren Heckrotte, Don Springer, Lewis Glen, Marvin Denny, Jay Zucca, Carl Poppe, Gail Bradshaw, and Lewis Dunn for their helpful comments on earlier drafts.

\section{$\underline{1950-1963}$}

Charles Appleby, Eisenhower and Arms Control, 1953-1961: A Balance of Risks (PhD Dissertation, Johns Hopkins University, 1987.)

Bernard Bechhoefer, Postwar negotiations for Arms Control (Brookings Institution, 1961).

Robert Divine, Blowing on the Wind: The Nuclear Test Ban Debate, 1954-1960 (New York: Oxford University Press, 1978).

Jacobson, Karan, and Stein, Diplomats, Scientists, and Politicians: The United States and the Nuclear Test Ban Negotiations (The University of Michigan Press, 1966).

Mary M. Leper, Foreign Policy Formulation: A Case Study of the Nuclear Test Ban Treaty of 1963 (Merrill Press, 1971).

Glenn T. Seaborg, Kennedy, Khrushchev, and the Test Ban (University of California Dress, Berkeley, 1981.)

$\underline{1964-1973}$

Jozef Goldblat, Ten Years of the Partial Test Ban Treaty, 1963-1973, SIPRI Research Report No. 11, August 1973.

R. Neild, "The Test Ban," SIPRI Yearbook 1972 (Stockholm, 1972), pp. 389-436.

Glen T. Seaborg (with Benjamin S. Loeb), Stemming the Tide: Arms Control in the Johnson Years, (Lexington Books, 1987.) 
Warren Heckrotte, "Verification of Test Ban Treaties," in William Potter (ed.), Verification and Arms Control (Lexington Books, 1985), pp. 63-80.

A. Karkoszka, "The Comprehensive Test Ban," SIPRI Yearbook 1978 (Stockholm, 1979), pp. 317-359.

House of Representatives Committee on Armed Services (Panel on the Strategic Arms Limitation Talks and the Comprehensive Test Ban Treaty), Effects of a Comprehensive Test Ban Treaty on United States National Security Interests (Government Printing Office, August 1978).

United Nations, Comprehensive Nuclear Test Ban, Report of the Secretary General, U.N. Document A/35/257, (May 1980).

U.S. Arms Control and Disarmament Agency, Arms Control and Disarmament Agreements: Tests and Histories of Negotiations, (Government Printing Office, 1982 ed.), pp. 164189.

U.S. Arms Control and Disarmament Agency, Documents on Disarmament series (Government Printing Office, 1977-1982).

Herbert York, Making Weapons, Talking Peace: A Physicist's Odyssey from Hiroshima to Geneva (Basic Books, 1987).

\section{$\underline{1982-1994}$}

Briefing on "The Administration, Congress and Nuclear Testing," Arms Control Today, (July/August 1993), pp 3-7.

Lockwood, Dunbar, "Drell Panel Criticizes Nuclear Warhead Safety Program," Arms Control Today, (January/February 1991), pp. 25-26.

Lockwood, D. "Officials Respond to Warhead Safety Report," Arms Control Today, (April 1991), p. 26.

Lockwood, D. "Clinton Moving Away from one-Kiloton Testing Proposal," Arms Control Today, (June 1993), p. 23. 
Lockwood, D. "Clinton Extends Test Moratorium; Lays Groundwork for CTB Talks, " Control Today (September 1993), p. 20.

Lockwood, D. "China's Nuclear Test Prompts U.S., Others to Review test Policies, " Arms Control Today, (November 1993), p. 28.

Thomas Schmalberger, In Pursuit of a Nuclear Test Ban Treaty: A Guide to the Debate in the Conference on Disarmament (United Nations Institute for Disarmament Research, UNIDIR 91/16, 1991.)

Oliver Thraeniert, Soviet Policy on Nuclear Testing, 1985-1991, The Martello Papers, No. 2, (Centre for International Relations, Queen's University, Kingston, Ontario, Canada, 1992.)

U.S. Department of Energy, Nuclear Testing Policy Documents and Chronology (1984-1990).

U.S. Government, The White House, Fact Sheet, "Background Information: U.S. Policy on Nuclear Testing and a Comprehensive Test Ban," July 3, 1993.

U.S. Arms Control and Disarmament Agency, Press Release, "UNGA First Committee Approves U.S. Co-sponsored Resolution on Comprehensive Test Ban Negotiations," November 19, 1993.

Tom A. Zamora, "LTBT Amendment Conference to Continue, But No Test Ban in Sight, " $\underline{\text { Arms }}$ Control Today, (April 1991), pp. 14-17.

\section{General Background}

April Carter, Success and Failure in Arms Control Negotiations, (Oxford University Press, 1989), pp. 79-104.

"Chronology of the Comprehensive Test Ban," Arms Control Today (November 1990), pp. 3135.

Steve Fetter, Toward a Comprehensive Test Ban (Ballinger Press, 1988), pp. 1-32.

G. Allen Greb, "Survey of Past Nuclear Test Ban Negotiations," in Jozef Goldblat and David Cox (eds.), Nuclear Weapon Test: Prohibition or Limitation? (Oxford University Press, 1988), pp. 95-118. 
Jozef Goldblat, "The Nuclear Explosion Limitation Treaties, " in Jozef Goldblat and David Cox (eds.), Nuclear Weapon Test: Prohibition or Limitation? (Oxford University Press, 1988), pp. 119-144.

Library of Congress, Congressional Research Service, Foreign Affairs and National Defense and Science Policy Research Divisions, Nuclear Weapons and Security: The Effects of Alternative Test Ban Treaties (Report for the U.S. House Foreign Affairs Committee), June 1989.

Stanford Arms Control Group, John H. Barton and Lawrence D. Weiler, (eds.), International Arms Control: Issues and Agreements (Stanford University Press, 1976), pp. 66-93.

U.S. National Academy of Sciences, Nuclear Arms Control: Background and Issues (National Academy Press, 1985), pp. 187-223. 

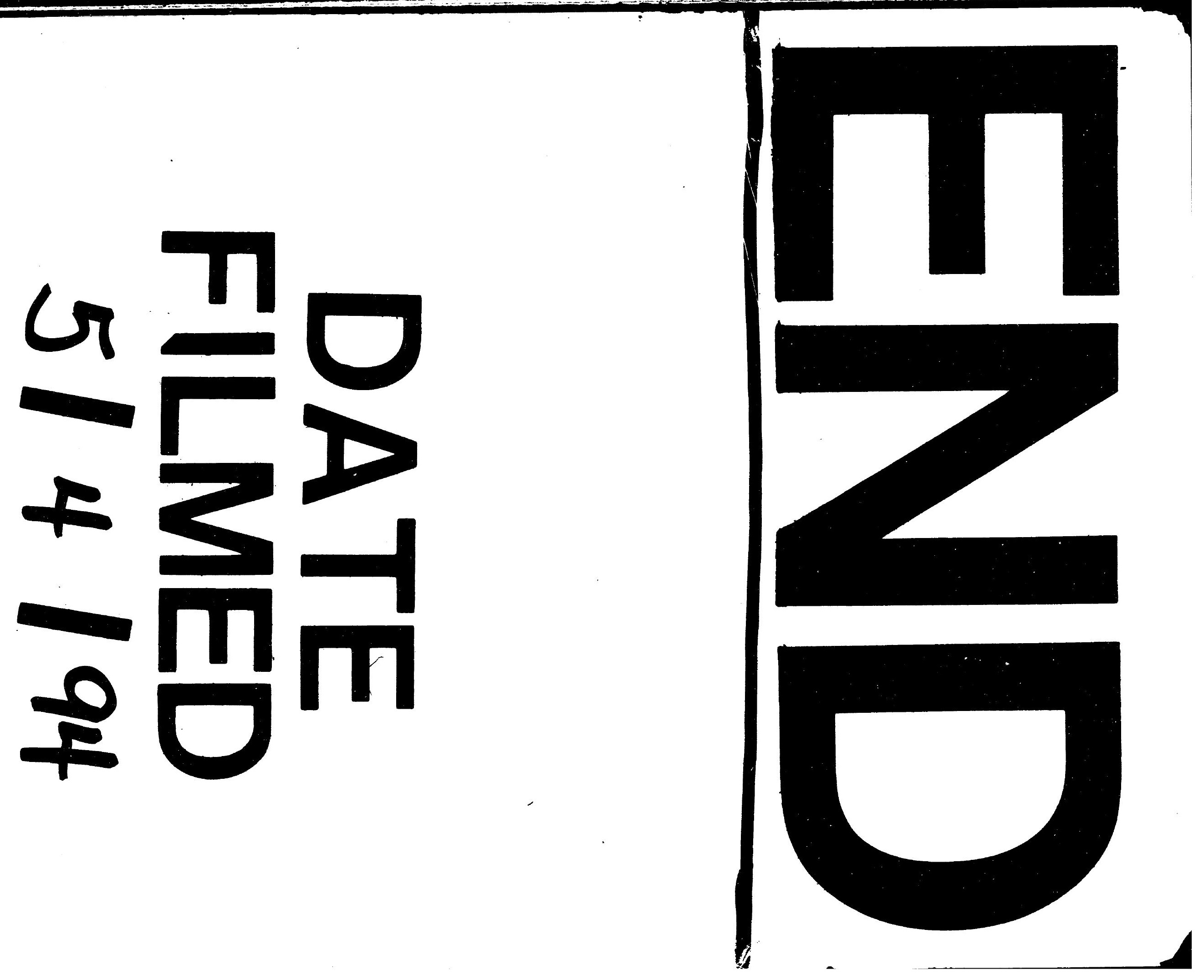
